\title{
A Statistical Analysis on Production of Chili and Its' Prospect in Bangladesh
}

\section{Sayed Mohibul Hossen}

Lecturer, Department of Statistics, Mawlana Bashani Science \& Technology University, Santosh, Tangail-1902, BANGLADESH

*Corresponding Contact:

Email: m300cht@gmail.com

Cell Phone: +8801914841480

\begin{abstract}
Chili is one of the most significant marketable crops of Bangladesh. It is grown almost all over the country. There are more than 400 different varieties of Chili's found all over the world. It is also called as hot pepper, sweet pepper, bell pepper, etc. Both chili and capsicum belong to same family as well as same genus that is Capsicum. C. frutescent is used for their small and very pungent fruits in hot sauces and as spices. It contains large amounts of vitamin C, small amounts of carotene (Provitamin A), vitamin B, vitamin B6, potassium, magnesium, and iron (USDA Nutrient Database). Bangladesh is one of the best producers, but there is no enough industry for preserving this fruit. So, all the production become indeed in consumption. The aim of the research is to know the cultural practices of chili in Bangladesh and how to make sweetened chili dishes that can play a vital role in our economy. This research considers the annual time series data for the period 2001-02 to 2010-11 and over seven divisions of Bangladesh. The data have been collected from various publications of BBS (Bangladesh Bureaus of Statistics) and BARC (Bangladesh Agriculture Research Council), the data of districts have been aggregated for seven divisions namely, Dhaka, Chittagong, Rajshahi, Khulna, Barisal, Sylhet, and Rangpur. Realizing the limitations of data availability, only nine variables are considered in the present research. Total production of Chili is taken as the dependent (endogenous) variable. The price of the Chili and seven divisions are considering as independent (exogenous) variables. The number of variables to be included in the model depends on the nature of the phenomenon under consideration and the purpose of the research.
\end{abstract}

Keyword: Chili, Production, Prospect, Bangladesh

\section{INTRODUCTION}

Bangladesh is one of the least developed countries in the world and facing numerous economic problems. The majority of its people depend on agriculture for earning their living. Agricultural development is still synonymous with the economic development of Bangladesh. All efforts will, therefore, be geared to provide the thrust necessary for boosting agricultural production. So the overall economic development depends on the proper development of our agricultural sector to great extent. 
In Bangladesh, most households always keep a stack of fresh hot green chilies at hand and use them to flavor most curries and dry dishes. It is typically lightly fried with oil in the initial stages of preparation of the dish by using spices and chilies (Dasgupta and Reshmi, 2011).

A few years ago, Chili may have been domesticated in our country but not cultivated commercially. In our country we have seen that maximum house had one or two chili plants in their house yard naturally. Now it is cultivated commercially in our country. It is an important fruit in many parts of the world for its production as spices. Mainly two types of Chili are cultured in our country commercially.

- Rabi Chili

- Karif Chili

The present study attempts to do a statistical analysis of current Chili production and its prospect in Bangladesh by considering the various sources of variations. The present study attempts to do a statistical analysis of current chili production and its prospect in Bangladesh but considering the various sources of variations on the time series data for 23 districts of Bangladesh and over a period of 10 years (2001-02 to 2010-11). The study is considered for whole Bangladesh.

\section{OBJECTIVES OF THE RESEARCH}

Chili is an important cash crop, which has huge demand in the domestic market as well as over in the world. In the present research, we attempt to construct a market model for Chili in Bangladesh with supply model.

The specific objectives are-

- Considering the importance of the Chili, we want to know the cultural practices of our agriculturists who produce Chili.

- We want to study a market model of Chili in Bangladesh and to identify the best model that may exist for forecasting purpose.

\section{Methodology}

The first and the main step for the econometrician are to study if there is any relationship with the variables and to express this relationship in precise form. That is to specify the model, with which the fiscal incident explore empirically.

\section{Regression analysis}

Regression analysis is a branch of statistical theory that is widely used in almost all the scientific disciplines. In economics, it is the technique for measuring or estimating the relationship with economic variables that constitute the essence of economic theory and economic life. With the help of regression analysis, we are in a position to find out the average probable change in one variable given a certain amount of change in another (Gujrati, D.N; 1995).

\section{Reason for using regression analysis}

The regression analysis helps in three significant ways:

- It provides estimates of values of the dependent variables from values of independent variables. The device used to accomplish the estimation procedure is the regression line that describes the average relationship existing between $\mathrm{x}$ and $\mathrm{y}$ variables.

- The second goal of regression analysis is to obtain a measure of the error involved in using the Regression line as a basis for estimations. For this purpose, the standard error of the estimate is calculated. If the line fits the data closely, that is, if there is relatively little scatter of the observations around the regression line, a good estimate can be made 
of the $y$ variable. On the other hand, if there is a great deal of scatter of the observations around the fitted regression line, the line will not produce accurate estimates of the dependent variable?

- With the help of regression analysis, we can obtain the measure of the degree of association or correlation that exists between the two variables. The coefficient of determination calculated for this purpose measures the strength of the relationship that exists between the variables. It assesses the proportion of variance by the regression equation.

\section{Hypothesis}

A basic economic theory is that for many commodities as price rises; the corresponding quantity supplied rises; as price falls, the quantity supplied also falls. That is there is a direct relationship between the price of the commodity and the quantity supplied.

$\mathrm{H}_{0}: \quad$ There is no relationship between price and production

$\mathrm{H}_{1}$ : There is a significant relationship between price and production

\section{Coefficient of determination}

The ratio of the unexplained variation to the total variation represents the proportion of variation in $y$ that is not explained by regression on $\mathrm{x}$. Subtraction of this from 1 gives the amount of variation in $\mathrm{y}$ that is explained by regression on $\mathrm{x}$. The statistic used to express this proportion is called the coefficient of determination and is denoted by $R^{2}$. It may be written as follows:

$R^{2}=1$ - (variation in y remaining after regression on $\mathrm{x}$ )/total variation in $\mathrm{y}$ $R^{2}=1$ - (error sum of squares)/total sum of squares

The value $R^{2}$ is the proportion of the variation in the dependent variable y explained by regression on the independent variable $x$.

\section{Factors affecting the supply model}

- The own price of the commodity: Quantity supply is influenced by the own price of the product under consideration. The quantity supplied, and prices are directly related. That is if the cost of a goods increase, quantity supplied increases and vice versa.

- The state of production technology: Any technological chance that decreases (increases) production costs will increase (decrease) the profits be able to earn at any given charge of the commodity under consideration. Since increased (decreased) profitability tends to lead to increased (decreased) production, this change will shift the curve to right (left). Indicating an increased (decreased) willingness or ability to produce the commodity and offer it for sale at each possible price.

- The cost of factors of production: A change in expenses of factors of production changes the Producers willingness to sell because it changes the cost of production and hence profit. A rise (fall) in the costs of factors of production sift supply curve of the commodity to the left (right), indicating that less (more) will be abounding at any given price.

- Price expectation: Expectations concerning the future price of a commodity can also affect the Producers current willingness to supply that product. Farmers might withhold some of their current chili harvests, from the current market or a higher guava price in future, which causes a shift in the supply curve to left.

- The number of buyers in the market: The larger the number of buyers in the market of the goods, the greater will be the market supply for that commodity. 


\section{RESULTS AND DISCUSSION}

The considered supply model is

$$
Y_{i t}=\beta_{1}+\beta_{2} X_{t}+u_{i t}
$$

Where, $Y_{i t}=$ total production of chili for i-th administrative

division by the $\mathrm{t}$-th year in Bangladesh

$X_{t}=$ prices of chili in $\mathrm{t}$-th year

$u_{i t}=$ disturbance terms

$\beta_{1}$ and $\beta_{2}$ are known as the regression coefficient. They also called as intercept and slope coefficients, respectively.

EQ.(1) can be written as follows:

$$
\begin{gathered}
Y i t=\widehat{\beta}_{1}+\widehat{\beta}_{2} X_{t}+\widehat{u}_{i t} \\
=\widehat{Y}_{i t}+\widehat{u}_{i t}
\end{gathered}
$$

Where $\hat{Y}_{i t}$ is the estimated value of $Y_{i t}$

Now we can write from Eq. (3)

$$
\begin{aligned}
& \widehat{u}_{i}=Y_{i t}-\widehat{Y}_{I t} \\
& \quad=Y_{i t}-\bar{\beta}_{1}-\widehat{\beta}_{2} X_{t} \ldots \ldots \\
& \sum \widehat{u}_{i}^{2}=\sum\left(Y_{i t}-\widehat{Y}_{i}\right)^{2} \\
& \quad=\sum\left(Y i t-\widehat{\beta}_{1}-\widehat{\beta}_{2} X_{t}\right)^{2}
\end{aligned}
$$

If $\sum \hat{u}_{i}^{2}$ is as small as possible we know how to estimate the coefficient $\beta_{1}$ and $\beta_{2}$ as follows:

$$
\begin{aligned}
& \sum Y_{i t}=n \widehat{\beta}_{1}+\widehat{\beta}_{2} \sum X_{t} \ldots \ldots \ldots \ldots \\
& \sum Y_{i t} X_{t}=\widehat{\beta}_{1} \sum X_{t}+\widehat{\beta}_{2} \sum X_{t}^{2}
\end{aligned}
$$

Solving the equations simultaneously, we obtain

$$
\begin{aligned}
& \hat{\beta}_{2}= \frac{n \sum X_{t} Y_{i t}-\sum X_{t} \sum Y_{i t}}{n \sum X_{t}^{2}-\left(\sum X_{t}\right)^{2}} \\
&= \frac{\sum\left(X_{t}-\bar{X}\right)\left(Y_{i t}-\bar{Y}\right)}{\sum\left(X_{t}-\bar{X}\right)^{2}} \\
&=\sum x_{i} y_{i} / \sum x_{i}^{2}
\end{aligned}
$$

Where, $\bar{X}$ and $\bar{Y}$ are the sample means of $\mathrm{X}$ and $\mathrm{Y}$. We define $x_{i}=(X t-\bar{X})$ and $y_{i}=\left(Y_{i t}-\bar{Y}\right)$.

And $\widehat{\beta}_{1}=\frac{\sum X_{i}^{2} \sum Y-\sum X_{i} Y}{n \sum X_{i}^{2}-\left(\sum X_{i}\right)^{2}}$ 


\begin{tabular}{|c|c|c|c|c|}
\hline \multicolumn{5}{|c|}{ Model Summary } \\
\hline Model & $\mathrm{R}$ & R Square & Adjusted R Square & Std. Error of the Estimate \\
\hline 1 & $.892 \mathrm{a}$ & .795 & .737 & 221.315 \\
\hline \multicolumn{7}{|l}{ a. Predictors: (Constant), Karif, Rabi } \\
\hline
\end{tabular}

\begin{tabular}{|c|c|c|c|c|c|c|}
\hline \multicolumn{7}{|c|}{ Coefficients } \\
\hline \multirow{2}{*}{\multicolumn{2}{|c|}{ Model }} & \multicolumn{2}{|c|}{ Unstandardized Coefficients } & \multirow{2}{*}{$\begin{array}{c}\text { Standardized Coefficients } \\
\text { Beta }\end{array}$} & \multirow[b]{2}{*}{$\mathrm{t}$} & \multirow[b]{2}{*}{ Sig. } \\
\hline & & B & Std. Error & & & \\
\hline \multirow[t]{2}{*}{1} & (Constant) & 56299.650 & 51943.869 & & 1.084 & .310 \\
\hline & Price & 81.998 & 23.106 & .782 & 3.549 & .008 \\
\hline \multicolumn{4}{|c|}{ a. Dependent Variable: Production } & & & \\
\hline
\end{tabular}

\section{Estimation of linear Regression model}

Estimating the parameters by OLS, we get

Supply: $\hat{Y}_{i t}=56299.650+81.998 X_{t}$

$$
\text { (.310) } \quad(.008) ; \quad R^{2}=.795
$$

\begin{tabular}{|c|c|c|c|c|c|c|}
\hline \multicolumn{7}{|c|}{ Coefficients } \\
\hline & & \multicolumn{2}{|c|}{ Unstandardized Coefficients } & \multirow{2}{*}{$\begin{array}{c}\text { Standardized Coefficients } \\
\text { Beta } \\
\end{array}$} & \multirow[b]{2}{*}{$\mathrm{t}$} & \multirow[b]{2}{*}{ Sig. } \\
\hline \multicolumn{2}{|c|}{ Model } & B & Std. Error & & & \\
\hline \multirow[t]{3}{*}{1} & (Constant) & 129.308 & 412.670 & & .313 & .763 \\
\hline & Rabi & .010 & .004 & .537 & 2.728 & .029 \\
\hline & Karif & .038 & .015 & .494 & 2.506 & .041 \\
\hline \multicolumn{3}{|c|}{ a. Dependent Variable: Price } & & & & \\
\hline
\end{tabular}

\section{Discussion}

The coefficient of determination $R^{2}$ of the equation is 0.795 , which indicates that $80 \%$ of the total variation Of the Dependent variable has been explained by the Independent variable. It can be said that the goodness of fit of the supply model is good on the average. A basic economic theory is that as price rises, the corresponding supply rises. Another economic hypothesis is that as production rises, the corresponding supply rises.

This result also suggests that, if the whole sale price increases thousand taka per ton then production/supply of Rabi chili and Karif chili will increase on the average by 537 and 494 metric ton respectively.

\section{Graphical Presentation of Data}

\section{Production of Rabi chili in seven divisions}

It is apparent from the graph below that the production of Rabi chili in seven divisions is increasing year to year. For the Chittagong and Dhaka division, the production has sharply improved in the year 2004-05. Again for Khulna, Barisal, and Rajshahi divisions the production has harshly increased in the year 2003-04. And for the Sylhet and Rangpur divisions' production is rising gradually. 


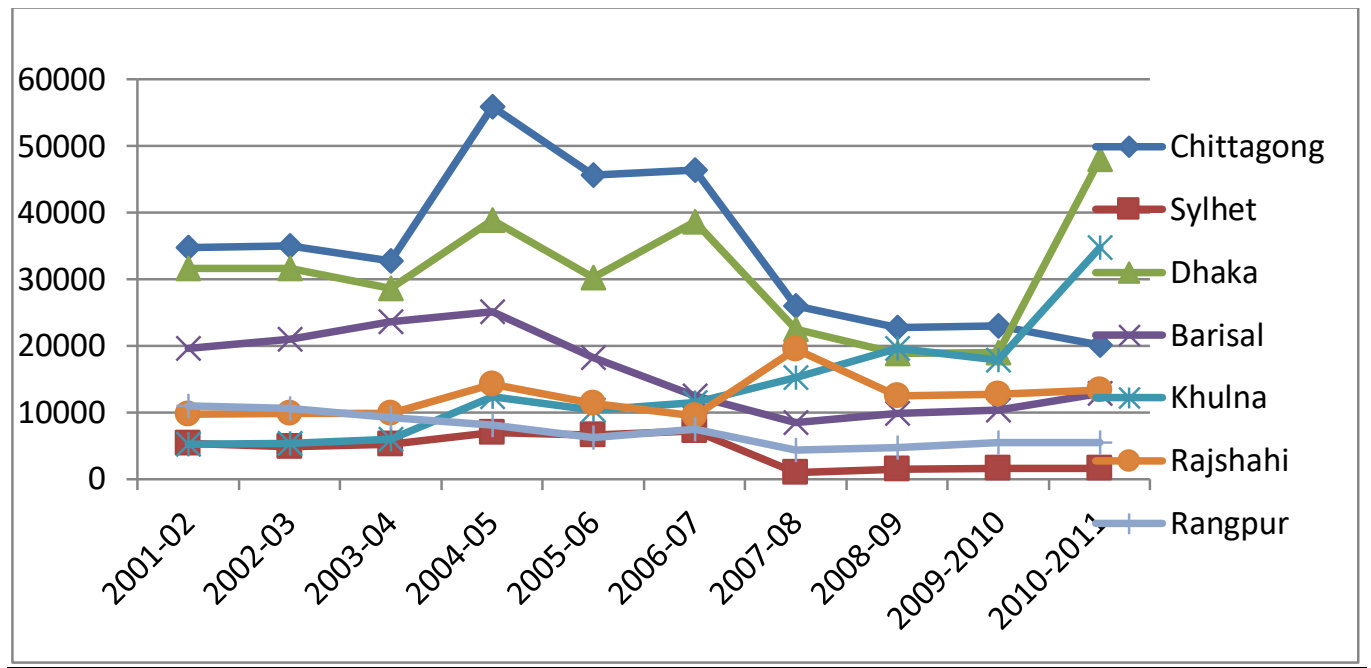

\section{Production of Rabi Chili}

\section{Production of Karif chili in seven divisions}

From the graph given below it is clear that the production of Karif chili in seven divisions is increasing year to year. For the Khulna division, the production has sharply augmented in the year 2010-11. Again for Dhaka, Barisal, and Rajshahi divisions the production has harshly increased in the year 2010-11. And for the Chittagong division production Karif chili is decreasing gradually.

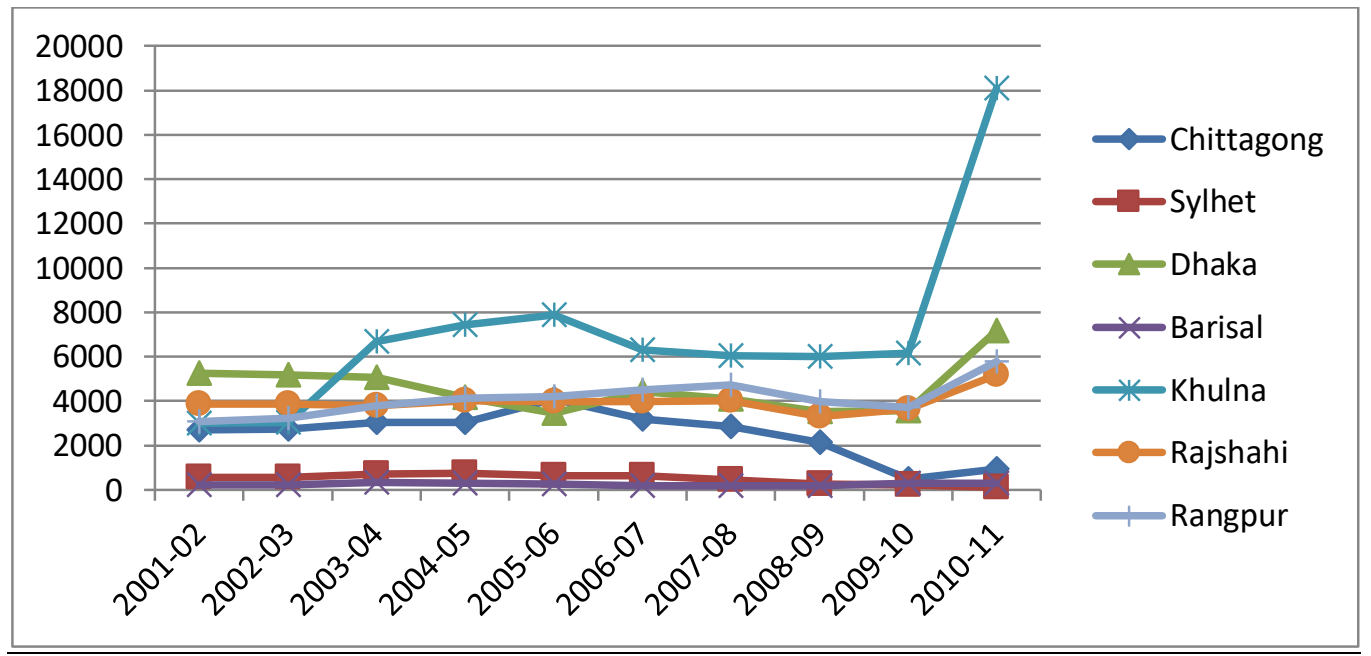

Production of Karif Chili

\section{Overall Production of chili in Bangladesh}

From the visual aid, we have seen that the production of chili in Bangladesh is increasing year to year. Moreover, the highest increase in the production of chili is in the year 2010-11, and the lowest was in the year 2008-09. 


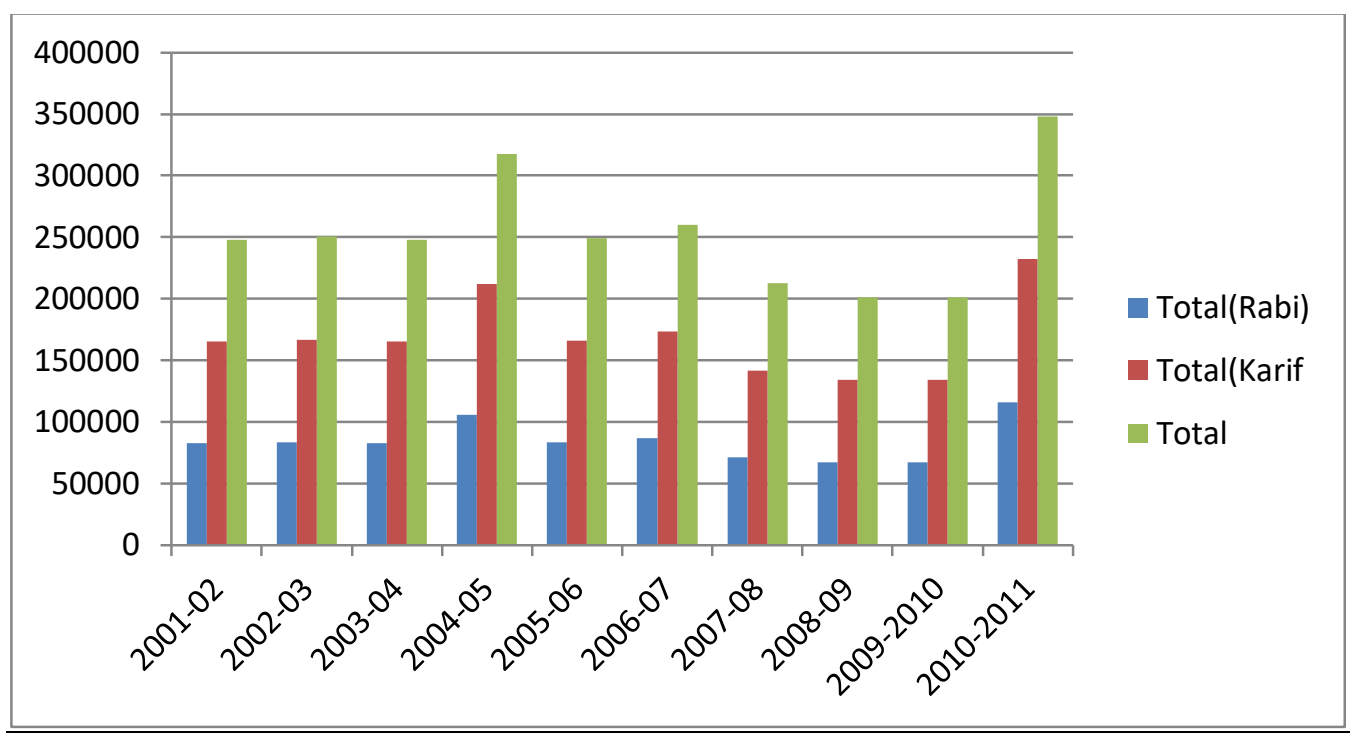

\section{CONCLUSION}

Finally, we have concluded that the production of chili in Bangladesh is increasing day by day. The soil and weather condition of our country is good for chili cultivation. From this analysis, it is clear that the quantity supplied is responsive to its price. Economic theory suggests that the coefficient of the price for supply equation is positive. That is, as expected price rises, the corresponding supply rises. This indicates that there is a direct relationship between expected price of chili and the quantity supplied.

\section{REFERENCES}

Araya, A., Girma, A., \& Getachew, F. (2015). Exploring Impacts of Climate Change on Maize Yield in Two Contrasting Agro-Ecologies of Ethiopia. Asian Journal Of Applied Science And Engineering, 4(1), 26-36.

BBS 2007-11: "Statistical year book of Bangladesh", 20007-11.Bangladesh Bureaus of Statistics, Dhaka.

Chile, L., \& Talukder, D. (2014). The Paradox of Agricultural Trade Liberalization in Bangladesh and

Tanzania.American Journal Of Trade And Policy, 1(1), 23-31.

Chili Pepper History \& Chili Pepper Glossar". www.thenibble.com. Retrieved 23 October 2013

Chowdhury, M., \& Chowdhury, A. (2015). Problems and Prospects of Potato Cultivation in Bangladesh. Asian Business Review, 5(1), 28-32.

Dasgupta, Reshmi R (8 May 2011). "Indian chili displacing jalapenos in global cuisine - The Economic Times." The Times of India.

Devi, K., Vijayalakshmi, P., Kumar, B., \& Talluri, V. (2014). Statistical Optimization of Kojic Acid Production through Response Surface Methodology by Aspergillus Flavus using Sago Starch Hydrolysate as a Carbon Source. Asian Journal Of Applied Science And Engineering, 3(5), 53-60.

Gujrati, D.N; 1995. Basic Econometrics, New York: Me Graw-Hill

Hajirostamlo, B., Mirsaeedghazi, N., Arefnia, M., Shariati, M., \& Fard, E. (2015). The Role of Research and Development in Agriculture and Its Dependent Concepts in Agriculture. Asian Journal Of Applied Science And Engineering, 4(1), 78-80.

History of Chili, Chili Con Carne. whatscookingamerica.net. 2004. Retrieved January 6, 2008.

Hossain, A., Khan, J., \& Miah, M. (2015). Distribution Process of Pesticides in Vegetable Production in the Southern Part of Bangladesh. Asian Business Review, 4(2), 20-24.

Hossen, S. (2015). Statistical Analysis of Current Guava Production and Its Prospect in Bangladesh. Asian Business Review, 1(1), 09-14.

http:/ / www.economicperception.com/ourbusiness / 
http:/ / www.eujournal.org/index.php/esj/article/download/5292...

Ilahi, H., Saadaoui, I., Bryant, C., \& Rejeb, H. (2014). Anthropized Agrarian Landscape in the Centralwest of Tunisia: Attempts to Evaluate the Production's Systems of Apples-trees Orchards in the Delegation of Sbiba. ABC Journal Of Advanced Research, 3(1), 34-43.

Katsaruware, R., \& Gwembire, J. (2014). Float Trays as an Alternative to Methyl Bromide in Tobacco Production in Hurungwe District, Zimbabwe. Asian Journal Of Applied Science And Engineering, 3(2), 119-128.

Khalequzzaman, K. (2015). Management of Anthracnose of Hyacinth Bean for Safe Fresh Food Production. Asian Journal Of Applied Science And Engineering, 4(2), 102-109.

Luo, C. (2015). Circular Economy and Urban Waste Resources Recycling. American Journal Of Trade And Policy, 1(3), 23-26.

Mekonen, M., Tesfaye, K., \& Bayu, W. (2013). Soil Drainage and Nutrient Management to Improve Productivity of Waterlogged Vertisols for Small-scale Farmers. Engineering International, 1(2), 27-39.

Mwase, D. (2015). Performance of Floriculture Industry in East Africa: What Lessons can Tanzania Learn from Kenya?. Asian Business Review, 5(1), 20-27.

Seid, M. (2013). Community Perception and Indigenous Adaptive Response to Climate Variability at Tehuledere Woreda, South Wollo. Engineering International, 1(2), 18-26.

USDA Nutrient Database

\section{APPENDIX}

Table 1: Production of Karif Chili

\begin{tabular}{|c|c|c|c|c|c|c|c|c|c|c|}
\hline Division & $2001-02$ & $2002-03$ & $2003-04$ & $2004-05$ & $2005-06$ & $2006-07$ & $2007-08$ & $2008-09$ & $2009-10$ & $2010-11$ \\
\hline Chittagong & 2695 & 2730 & 3025 & 3040 & 4105 & 3210 & 2860 & 2156 & 486 & 930 \\
\hline Sylhet & 555 & 570 & 710 & 740 & 640 & 640 & 460 & 269 & 228 & 106 \\
\hline Dhaka & 5260 & 5190 & 5055 & 4185 & 3460 & 4415 & 4085 & 3516 & 3571 & 7169 \\
\hline Barisal & 215 & 225 & 320 & 305 & 280 & 185 & 175 & 173 & 289 & 287 \\
\hline Khulna & 2990 & 3025 & 6685 & 7445 & 7895 & 6320 & 6065 & 6016 & 6162 & 18117 \\
\hline Rajshahi & 3885 & 3870 & 3780 & 4035 & 3965 & 3965 & 4020 & 3307 & 3656 & 5201 \\
\hline Rangpur & 3085 & 3230 & 3810 & 4115 & 4205 & 4505 & 4730 & 3997 & 3712 & 5781 \\
\hline Total & 18685 & 18840 & 23385 & 23865 & 24550 & 23240 & 22395 & 19434 & 18104 & 37591 \\
\hline
\end{tabular}

- Production of Karif Chili in seven divisions

- Production in Metric ton

Table 2: Production of Rabi Chili

\begin{tabular}{|c|c|c|c|c|c|c|c|c|c|c|}
\hline Division & $2001-02$ & $2002-03$ & $2003-04$ & $2004-05$ & $2005-06$ & $2006-07$ & $2007-08$ & $2008-09$ & $2009-10$ & $2010-11$ \\
\hline Chittagong & 34765 & 35040 & 32820 & 55925 & 45690 & 46465 & 26014 & 22752 & 23029 & 20098 \\
\hline Sylhet & 5285 & 4820 & 5205 & 6955 & 6580 & 7220 & 1017 & 1525 & 1616 & 1645 \\
\hline Dhaka & 31645 & 31660 & 28670 & 38945 & 30245 & 38660 & 22476 & 18856 & 18965 & 48019 \\
\hline Barisal & 19605 & 21005 & 23616 & 25150 & 18210 & 12430 & 8438 & 9852 & 10369 & 12844 \\
\hline Khulna & 5265 & 5400 & 5985 & 12410 & 10365 & 11475 & 15205 & 19678 & 17819 & 34768 \\
\hline Rajshahi & 9770 & 9900 & 9830 & 14280 & 11395 & 9420 & 19532 & 12537 & 12776 & 13295 \\
\hline Rangpur & 10960 & 10660 & 9235 & 8105 & 6265 & 7425 & 4285 & 4703 & 5468 & 5446 \\
\hline Total & 117295 & 118485 & 115361 & 161770 & 128750 & 133095 & 96967 & 89903 & 90042 & 136115 \\
\hline
\end{tabular}

- Production of Rabi Chili in seven divisions

- Production in Metric ton 